\title{
Physiological responses of Rhamdia quelen (Siluriformes: Heptapteridae) to anesthesia with essential oils from two different chemotypes of Lippia alba
}

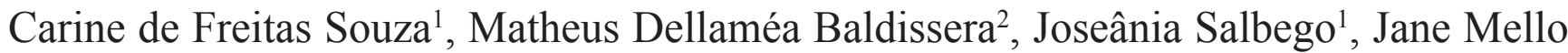 \\ Lopes $^{3}$, Rodrigo de Almeida Vaucher ${ }^{4}$, Rosa Helena Veras Mourão ${ }^{5}$, Braulio O. Caron ${ }^{6}$, \\ Berta Maria Heinzmann ${ }^{7}$, Lenise Vargas Flôres da Silva ${ }^{8}$ and Bernardo Baldisserotto ${ }^{1}$
}

The aim of this study was to evaluate if Lippia alba has different chemotypes according to the chemical composition of the essential oil (EO) considering collection site, and if the EO may have different effects on blood and plasma parameters in silver catfish, Rhamdia quelen, during and immediately after anesthesia. The citral (EO-C) and linalool (EO-L) chemotypes were identified, and both presented similar anesthetic effects for silver catfish. Fish were exposed to two concentrations of each EO, which induced slow and fast anesthesia (100 and $300 \mu \mathrm{L} \mathrm{L}^{-1}$, respectively). Blood ions did not change at any time of anesthesia induction and recovery and, therefore, the electrolyte balance was not altered. Blood gases oscillated through all exposure and recovery times, but there was an increase in $p \mathrm{O}_{2}$ after 10 min recovery in fish anesthetized with EO-C. Glucose increased in fish exposed to both EOs when compared with the control group. Overall, exposure to both EOs (except $100 \mu \mathrm{L}$ $\mathrm{L}^{-1}$ EO-L at most times) reduced plasma cortisol levels compared to the control and/or ethanol groups. However, as plasma creatinine levels in fish anesthetized with EO-C were higher than control fish, the use of EO-L is preferable.

Keywords: Blood gas, Cortisol, Glucose, Plasma ions, Silver Catfish.

O objetivo deste estudo foi avaliar se Lippia alba apresenta diferentes quimiotipos de acordo com a composição química do óleo essencial (OE), considerando local de coleta e se o OE causa diferentes efeitos nos parâmetros sanguíneos e plasmáticos em jundiá, Rhamdia quelen, durante e imediatamente após a anestesia. Os quimiotipos citral (OE-C) e linalol (OE-L) foram identificados e ambos apresentaram efeito anestésico semelhante para jundiá. Os peixes foram expostos a duas concentrações de cada $\mathrm{OE}$, que induziram anestesia lenta e rápida (100 e $300 \mathrm{~mL} \mathrm{~L}^{-1}$, respectivamente). Íons sanguíneos não se alteraram em nenhum tempo e consequentemente, o equilíbrio eletrolítico não foi alterado. Os gases sanguíneos oscilaram durante todo tempo de exposição e recuperação, mas houve aumento na $p \mathrm{O}_{2}$ após 10 min de recuperação em peixes anestesiados com OEC. Níveis sanguíneos de glicose aumentaram nos peixes expostos a ambos OEs quando comparados com o grupo controle. De um modo geral, a exposição a ambos OEs (exceto $100 \mu \mathrm{L} \mathrm{L}^{-1} \mathrm{OE}-\mathrm{L}$ na maioria dos tempos) reduziu o cortisol plasmático comparado aos grupos controle e etanol. No entanto, como os níveis de creatinina plasmática em peixes anestesiados com OE-C foram maiores que nos peixes controle, é preferível o uso do OE-L.

Palavras-chave: Cortisol, Gases sanguíneos, Glicose, Íons plasmáticos, Jundiá.

\footnotetext{
${ }^{1}$ Departamento de Fisiologia e Farmacologia, Universidade Federal de Santa Maria - UFSM, Av. Roraima, 1000, Camobi, 97105-900 Santa Maria, RS, Brazil. (CFS) carinedefs@yahoo.com.br, (JS) josalbego2004@yahoo.com.br, (BB) bbaldisserotto@hotmail.com (corresponding author)

${ }^{2}$ Departamento de Microbiologia e Parasitologia, Universidade Federal de Santa Maria - UFSM, Av. Roraima, 1000, Camobi, $97105-900$ Santa Maria, RS, Brazil. matheusd.biomed@yahoo.com.br

${ }^{3}$ Universidade Federal do Maranhão, Campus de Chapadinha, 65500-000 Chapadinha, MA, Brazil. janemellolopes@hotmail.com

${ }^{4}$ Laboratório de Cultura Celular, Centro Universitário Franciscano, Rua dos Andradas, 1614, 97010-032 Santa Maria, RS, Brazil. rodvaucher@hotmail.com

${ }^{5}$ Programa de Pós-Graduação em Recursos Naturais da Amazônia, Laboratório de Bioprospecção e Biologia Experimental, Universidade Federal do Oeste do Pará-UFOPA, Rua Vera Paz, s/n, 68035-110 Santarém, PA, Brazil. mouraorhv@yahoo.com.br

${ }^{6}$ Departamento de Agronomia e Ciências Ambientais, Universidade Federal de Santa Maria, Centro de Educação Superior Norte do Rio Grande do Sul, Linha 7 de Setembro, s/n, 98400-000 Frederico Westphalen, RS, Brazil. otomarcaron@yahoo.com.br

${ }^{7}$ Departamento de Farmácia Industrial, Universidade Federal de Santa Maria - UFSM, Av. Roraima, 1000, Camobi, 97105-900 Santa Maria, RS, Brazil. berta.heinzmann@gmail.com

${ }^{8}$ Instituto de Ciências e Tecnologia das Águas, Universidade Federal do Oeste do Pará (UFOPA), Rua Vera Paz, s/n, 68035-110 Santarém, Pará, Brazil. lvfrsi@yahoo.com.br
} 


\section{Introduction}

In aquaculture, anesthetics (synthetics or plant extratives) are widely employed: from light sedation, to reduce stress during handling and non-invasive procedures, to full anesthesia to avoid pain during surgery and larger interventions (Small, 2003; Roubach et al., 2005; Ross, Ross, 2008; Kiessling et al., 2009; Neiffer, Stamper, 2009; Silva et al., 2013a; Roohi, Imanpoor, 2015).

The anesthetic efficacy of several essential oils (EOs), such as Hyptis mutabilis (Silva et al., 2013a), Ocotea acutifolia (Silva et al., 2013b), Hesperozygis ringens (Silva et al., 2013b; Toni et al., 2014), Aloysia triphylla (Parodi et al., 2014) and Ocimum gratissimum (Silva et al., 2015), has been demonstrated in fish. The EO of Lippia alba has been highlighted in the last decade through studies reporting its potential as antioxidant, anesthetic and sedative for fish (Cunha et al., 2010; Becker et al., 2012; Heldwein et al., 2014; Toni et al., 2014; Hohlenwerger et al., 2016).

Lippia alba occurs in all regions of Brazil (Zétola et al., 2002; Oliveira et al., 2006; Neto et al., 2009; Cunha et al., 2010; Teles et al., 2012; Vale et al., 2012; Soares et al., 2016). Due to its genetic variation, wide geographical distribution and exposure to different soil and weather conditions, and distinct seasons of collection, $L$. alba can produce EOs with different chemical composition, which expresses the occurrence of distinct chemotypes (Pascual et al., 2001; Hennebelle et al., 2008; Maffei et al., 2011; Teles et al., 2012). There are numerous chemotypes of $L$. alba in Brazil, such as: citral, linalool, $\beta$-caryophyllene, tagetenone, limonene, carvone, myrcene, $\gamma$-terpinene, camphor-1,8-cineole and estragole, which produce different pharmacological effects (Oliveira et al., 2006; Hennebelle et al., 2008; Vale et al. 2012; Viccini et al., 2014). Thus, the distinct composition of same EO may result in different physiological and pharmacological effects during anesthesia.

Hematological and biochemical parameters of fish are valuable markers, since they can be used as indicators of physiological conditions, as well as in the control of diseases and stress manipulation (Aldrin et al., 1982; TavaresDias et al., 2008; Araújo et al., 2009). Plasma cortisol is one of the most used indicators to evaluate stress in fish (Wendelaar Bonga, 1997) and the two major actions of this hormone are the control of the ionoregulatory balance and energy metabolism (Liew et al., 2015). The electrolytic imbalance can be observed by changes in plasma or blood ions (McDonald, Milligan, 1997; Wendelaar Bonga, 1997; Takahashi et al., 2006). Glucose levels are also widely used as indicator of stress, hyperglycaemia being reported for several teleosts in this situation (Barton, Iwama, 1991). Stress also has an effect on other blood biochemical parameters such as levels of enzymes and substances with important metabolic functions, such as urea and creatinine, which indicate the overall health of the fish (Cnaani et al., 2004).
Physiological effects of the EO of $L$. alba cultivated in southern Brazil as anesthetic and sedative for silver catfish, Rhamdia quelen, was verified by many authors (Cunha et al., 2010; Heldwein et al., 2014; Toni et al., 2014; Salbego et al., 2014), but only the linalool chemotype. Therefore, it is of interest to investigate the anesthetic and physiological effects of EO obtained from other chemotypes of $L$. alba. Considering that a different chemotype of $L$. alba (myrcenecitral) cultivated in northern Brazil was identified by Oliveira et al. (2006), the aim of this study was to investigate a possible geographic effect in the EO composition ( $L$. alba cultivated in northern and southern Brazil) and, if these EOs have different compositions, to evaluate their sedative and anesthetic effects in silver catfish, as well as their physiological effects on blood and plasma parameters.

\section{Materials and Methods}

Animals. One hundred sixty-eight juveniles silver catfish (Rhamdia quelen; $51.17 \pm 1.69 \mathrm{~g}$ and $20.21 \pm 1.40 \mathrm{~cm}$ ) were obtained from a local fish farm and brought to the Fish Physiology Laboratory at the Universidade Federal de Santa Maria (UFSM). The species was identified at the Ichthyology Laboratory (Universidade Federal do Rio Grande do Sul) and a voucher specimen was deposited in this laboratory at number UFRGS 19612. The fish were maintained for one week in $250 \mathrm{~L}$ tanks (50 fish/tank) with continuous aeration; temperature $21 \pm 2{ }^{\circ} \mathrm{C}$; $\mathrm{pH}$ 6.5-7.5 and dissolved oxygen above $5.5 \mathrm{mg} \mathrm{L}^{-1}$. The animals were fed once a day with commercial feed and kept fasted for a period of $24 \mathrm{~h}$ prior to the experiments. The experimental protocol was approved by the Committee on Animal Experimentation - UFSM, under the registration number 074/2014.

Essential oils extraction and analysis. The specimens of Lippia alba linalool chemotype were cultivated at the Centro de Educação Superior do Norte (CESNORS-UFSM) - Frederico Westphalen, Rio Grande do Sul State, southern Brazil (27 $23^{\prime} 48^{\prime \prime}$ S, 53 $\left.25^{\prime} 45^{\prime \prime} \mathrm{W}\right)$, soil classified as Oxisol typical clayey. The climate is $\mathrm{Cfa}$ (humid subtropical) with average annual temperature of $19.1{ }^{\circ} \mathrm{C}$ and rainfall of $1892 \mathrm{~mm}$. Those from the citral chemotype were cultivated in Santarém, Pará state, northern Brazil $\left(02^{\circ} 26^{\prime 3} 35^{\prime \prime} \mathrm{S}\right.$, 054 $\left.54^{\prime} 54^{\prime \prime} \mathrm{W}\right)$, soil classified as ultisol yellow Hapludox + yellow latosol Hapludox, but in the culture it was used black soil and cattle manure (3:1). The climate is Am (humid tropical) with average annual temperature of $25.9^{\circ} \mathrm{C}$ and rainfall of 2,150 mm.

Botanical identification of $L$. alba linalool chemotype was made by Gilberto Dolejal Zanetti (Department of Industrial Pharmacy, UFSM) and a voucher specimen (SMDB 10050) was deposited in the herbarium of the Department of Biology (UFSM). The L. alba citral chemotype was identified by Dr. Fatima Salimena (Universidade Federal de Juiz de Fora) and a voucher was registered in the herbarium of this institution under number CESJ 65276. 
The essential oils were obtained by hydrodistillation of fresh leaves for $3 \mathrm{~h}$ in a Clevenger apparatus (European Pharmacopoeia, 2007) and stored at $-4^{\circ} \mathrm{C}$ until utilization. The analysis of the EOs was performed by gas chromatographymass spectrometry-total ion chromatogram using an Agilent 6890 gas chromatograph coupled with an Agilent 5973 mass selective detector and employing a HP5-MS column $(5 \%$ phenyl, $95 \%$ methylsiloxane, $30 \mathrm{~m}$ x $0.25 \mathrm{~mm}$ i.d. x 0.25 $\mathrm{mm}$ ) as described by Silva et al. (2012). The constituents were identified by comparison of the Kovats retention index and their mass spectra with data from the mass spectral library (NIST, 2002) and the literature (Adams, 2001).

Experiment 1. Anesthetic induction and recovery times. Anesthesia induction and recovery were tested at concentrations of $25,50,100,200,300 \mu \mathrm{L} \mathrm{L}^{-1}$ for both EOs. Eight fish were used for each concentration tested, and each juvenile was used only once. Sedation was characterized by the decreased reactivity to external stimuli, and anesthesia by total loss of equilibrium and cessation of locomotion, according to Small (2003). The EOs were previously diluted in $95 \%$ ethanol (1:10). Ethanol at the highest concentration used does not have any anesthetic effect in silver catfish (Cunha et al., 2010). After induction, fish were transferred to anesthetic-free aquaria to measure anesthesia recovery time. The fish were considered to be recovered when they returned to normal swimming and reacted to external stimuli.

Experiment 2. Exposure to anesthetics for physiological evaluation. Silver catfish were individually placed in an 8 $\mathrm{L}$ aquarium containing one of the EOs at $100 \mu \mathrm{L} \mathrm{L}^{-1}$ for up to $5 \mathrm{~min}$ or $300 \mu \mathrm{L} \mathrm{L}^{-1}$ for up to $2 \mathrm{~min}$. These concentrations led to sedation and deep anesthesia, respectively (Cunha et al., 2010). Afterwards, fish from all groups were transferred individually to $8 \mathrm{~L}$ aquaria with anesthetic-free water for up to $10 \mathrm{~min}$ for recovery. There were also groups subjected to $26700 \mu \mathrm{L} \mathrm{L}^{-1}$ ethanol (the concentration used to dilute the highest EO concentration) and water only (control), which were handled as outlined above.

Blood analysis. Blood was collected from the caudal vein of silver catfish in less than $30 \mathrm{~s}$ with heparinized syringes at 1,2 and $5 \mathrm{~min}$ of exposure (groups exposed to the concentration of $300 \mu \mathrm{L} \mathrm{L}^{-1}$ were not assessed at $5 \mathrm{~min}$ ) and 5 and 10 min of recovery (total of 30 fish per treatment, $\mathrm{n}=6$ for each EO, concentration and collection time, each fish was sampled only once). Control and ethanol exposed fish were held tightly for blood collection. An aliquot of this blood was used to measure $\mathrm{Na}^{+}, \mathrm{K}^{+}, \mathrm{Ca}_{2}{ }^{+}$, glucose, $\mathrm{pH}$, partial pressures of $\mathrm{O}_{2}\left(p \mathrm{O}_{2}\right)$ and $\mathrm{CO}_{2}\left(p \mathrm{CO}_{2}\right)$ using the i-STAT ${ }^{\circledast}$ portable clinical analyzer with CG8+ cartridges (Abbott Laboratories, Chicago, IL, USA). The sample temperature was corrected to match the experimental water temperature (Roth, Rotabakk, 2012). The use of i-STAT ${ }^{\circledR}$ and calculations for blood gases have been described for several fish species (Jacobs et al., 1993; Pidetcha et al.,
2000; Harrenstien et al., 2005; Kristensen et al., 2010; Barbas et al., 2016).

Plasma analysis. The remaining blood collected was centrifuged $(800 x \mathrm{~g}$ for $10 \mathrm{~min}$ ) and the plasma was used for analysis of creatinine and urea using an automated Vitros 250 (Ortho - Clinical Diagnostics) and Johnson \& Johnson dry chemistry kits. All tests were carried out in duplicate.

Plasma cortisol was also determined in duplicate using an enzyme-linked immunosorbent assay (ELISA) kit (Diagnostics Biochem Canada Inc., Canada). This analysis was previously validated (Souza et al., 2015). Absorbance was measured in a spectrophotometer at $450 \mathrm{~nm}$, and intraand inter-assay coefficients of variation were $6.3 \%$ and $5.2 \%$, respectively.

Statistical analysis. Data are reported as mean \pm SE. The homogeneity of variances among groups was determined with the Levene test. All treatment groups were compared by two-way analysis of variance (time $\mathrm{x}$ concentration) and Tukey's test; or, when homogeneity of variances was not obtained, by the Scheirer-Ray-Hare extension of the Kruskal-Wallis test and the Nemenyi test. Analyses were performed using the STATISTICA software package, version 5.1 (StatSoft, Tulsa, OK, USA), and the minimum significance level was set at $p<0.05$.

\section{Results}

Chemical composition of the essential oils. A total of 65 compounds were identified in the EO of $L$. alba collected in southern Brazil (EO-L) and 67 compounds in the EO of $L$. alba collected in northern Brazil (EO-C) (Tab. 1). The major component in the EO-L was $\beta$-linalool $(50.56 \%)$, while the major compounds in the EO-C were E-citral (29.84\%) and Z-citral (24.41\%).

Anesthetic induction and recovery times. Both EO-C concentrations induced sedation faster than EO-L, but anesthesia was faster only at the lowest EO-C concentration. Fish anesthetized with EO-C took longer to recover than those anesthetized with EO-L (Fig. 1). Ethanol did not show any sedative or anesthetic effect.

Blood analysis. Blood $\mathrm{pH}, \mathrm{Na}^{+}, \mathrm{K}^{+}$and $\mathrm{Ca}^{2+}$ did not differ between any of the treatments and overall means were: $\mathrm{pH}$ (7.32 \pm 0.04$), \mathrm{Na}^{+}\left(134.90 \pm 0.89 \mathrm{mmol} \mathrm{L}^{-1}\right), \mathrm{K}^{+}(2.89 \pm 0.12$ mmol L-1), $\mathrm{Ca}^{2+}\left(1.18 \pm 0.06 \mathrm{mmol} \mathrm{L}^{-1}\right)$.

Overall, blood $p \mathrm{O}_{2}$ levels of silver catfish anesthetized with both EOs and exposed to ethanol were lower than control fish, increasing after 10 min recovery (Figs. 2a-b). In contrast, an increase in $p \mathrm{CO}_{2}$ was observed for fish anesthetized with EO-C and no significant change was observed for silver catfish anesthetized with EO-L. At the end of 10 min of recovery fish anesthetized with EO-C still maintained blood $\mathrm{PCO}_{2}$ levels higher than control fish (Figs. 2c-d). 
Tab. 1. Chemical composition of the essential oils of Lippia alba collected from southern (linalool chemotype - EO-L) and northern (citral chemotype - EO-C) Brazil. RI calc $=$ calculated Kovats retention index; RI ref $=$ reference Kovats retention index; (Adams, 2001; NIST, 2002).

\begin{tabular}{|c|c|c|c|c|c|}
\hline \multirow{2}{*}{ RT (min) } & \multirow{2}{*}{ Constituent } & \multicolumn{2}{|c|}{ Relative percentage $(\%)$} & \multirow{2}{*}{ RI calc } & \multirow{2}{*}{ RI ref } \\
\hline & & EO-L & $\mathrm{EO}-\mathrm{C}$ & & \\
\hline 11.334 & sabinene & 1.05 & 0.47 & 972 & $968^{1,2}$ \\
\hline 13.597 & limonene & 0.63 & 6.15 & 1026 & $1029^{2}$ \\
\hline 13.698 & 1,8-cineole & 7.01 & - & 1029 & $1031^{1,2}$ \\
\hline 14.535 & E- $\beta$-ocimene & 1.10 & 0.35 & 1049 & $1050^{1}$ \\
\hline 14.882 & $\gamma$-terpinene & - & 3.16 & 1058 & $1060^{1}$ \\
\hline 16.623 & $\beta$-linalool & 50.56 & 0.73 & 1100 & $1099^{2}$ \\
\hline 21.599 & Z-geraniol & 0.49 & 3.57 & 1229 & $1230^{1}$ \\
\hline 22.037 & Z-citral & - & 24.41 & 1241 & $1238^{1,2}$ \\
\hline 22.587 & E-geraniol & 0.17 & 5.32 & 1256 & $1253^{1}$ \\
\hline 23.131 & E-citral & 1.51 & 29.84 & 1270 & $1267^{1,2}$ \\
\hline 27.375 & $\beta$-elemene & 2.66 & 0.30 & 1391 & $1391^{1,2}$ \\
\hline 28.291 & E-caryophyllene & 4.56 & 0.99 & 1418 & $1419^{1}$ \\
\hline 28.758 & $\gamma$-elemene & 1.27 & 0.08 & 1433 & $1437^{1}$ \\
\hline 30.174 & $\gamma$-muurolene & 5.23 & 2.46 & 1476 & $1480^{1}$ \\
\hline 30.815 & bicyclogermacrene & 0.22 & 3.72 & 1495 & $1500^{1}$ \\
\hline 32.47 & elemol & 0.13 & 3.15 & 1549 & $1550^{1}$ \\
\hline 32.717 & germacrene B & 2.37 & 0.23 & 1557 & $1561^{1}$ \\
\hline \multirow[t]{2}{*}{33.532} & caryophyllene oxide & 1.12 & 0.80 & 1584 & $1583^{2}$ \\
\hline & $\%$ Identified & 80.08 & 85.73 & & \\
\hline
\end{tabular}

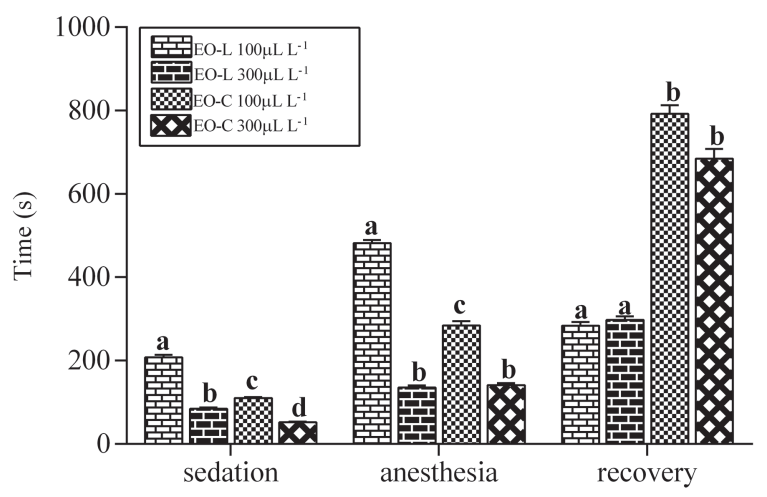

Fig. 1. Time required for silver catfish (Rhamdia quelen) anesthesia induction and recovery ( $n=8$ for each concentration tested) using different concentrations of essential oils from the linalool (EO-L) and citral (EO-C) chemotypes of Lippia alba. Stages are defined according to Small (2003). Values are mean \pm SEM. Different letters indicate difference between concentrations and EOs in the same anesthetic stage. Based on two-way ANOVA followed by the Tukey post hoc test $(\mathrm{p}<0.05)$.

Blood glucose levels increased in control and ethanol groups after $5 \mathrm{~min}$, compared to initial values, returning to initial values at the end of the recovery period in the control group. Exposure to both EOs (except $300 \mu \mathrm{L} \mathrm{L}^{-1}$ EO-L) did not avoid this increase of blood glucose levels.
At the end of the recovery period, the blood glucose levels of silver catfish exposed to ethanol and both EOs (except $300 \mu \mathrm{L} \mathrm{L}^{-1}$ EO-L) remained higher than the initial values and higher than those of the control group (Figs. 3a-b).

In the control group, plasma cortisol levels decreased after $2 \mathrm{~min}$ and remained low until the end of the recovery period. In fish exposed to ethanol, cortisol levels decreased up to $5 \mathrm{~min}$ after exposure and returned to the initial values after $5 \mathrm{~min}$ of recovery. Overall, exposure to both EOs (except $100 \mu \mathrm{L} \mathrm{L}^{-1}$ EO-L at most times) reduced plasma cortisol levels compared to the control and/or ethanol groups (Figs. 3c-d).

Plasma creatinine values of control fish increased significantly after $5 \mathrm{~min}$ and remained high at the end of the recovery period. Fish exposed to ethanol and both EOs showed significantly higher creatinine levels $1 \mathrm{~min}$ after exposure compared to control fish and these levels returned to control values at the end of recovery only in those exposed to EO-L (Figs. 4a-b). Plasma urea levels in the control group remained constant at all evaluation times. Fish exposed to ethanol showed a significant increase in plasma urea levels when compared to control fish after 5 min of exposure and returned to control values at the end of the recovery period. Plasma urea was significantly higher with most anesthesia treatments and recovery times in fish exposed to both EOs when compared to the control and ethanol groups (Figs. 4c-d). 

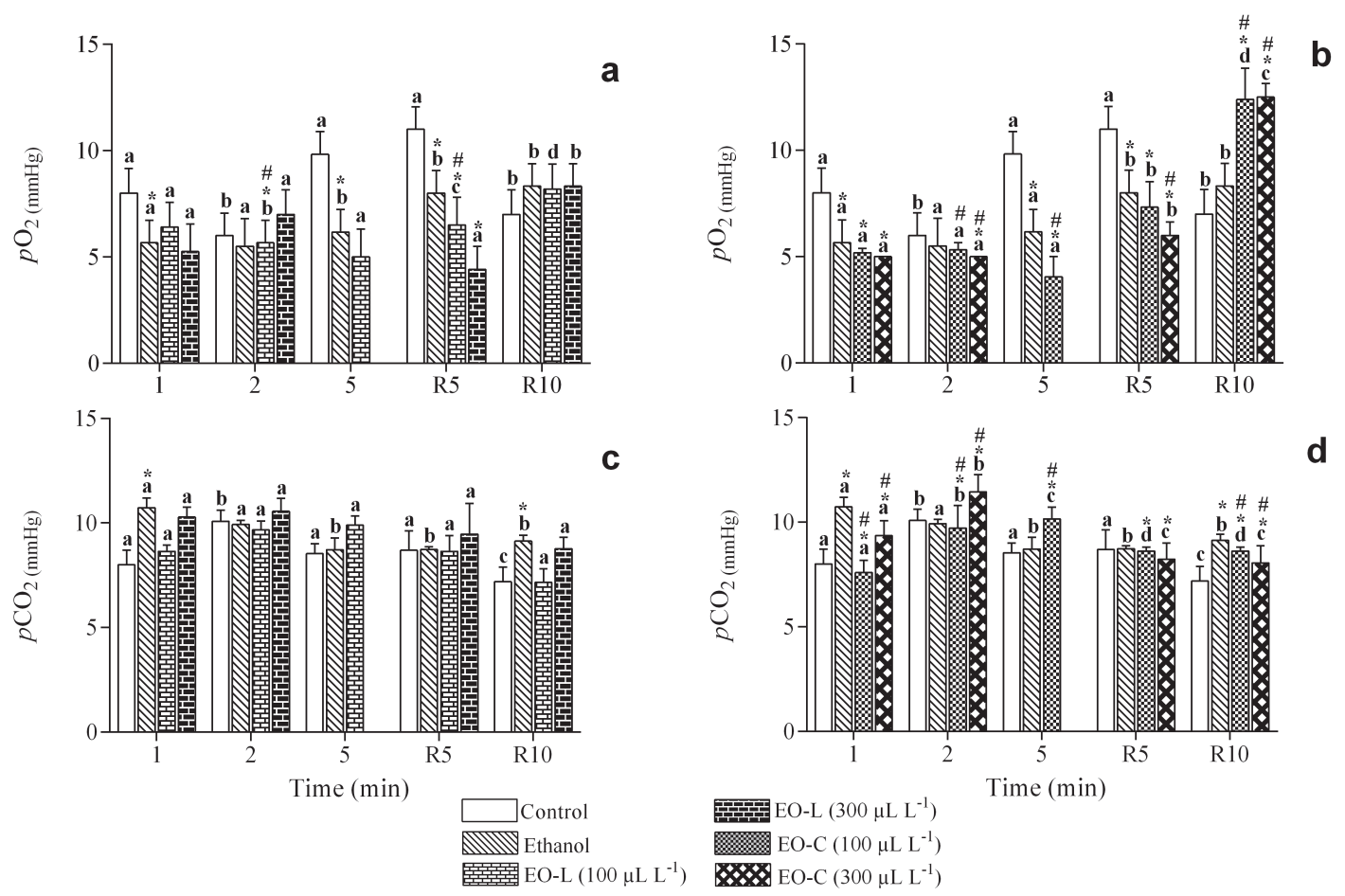

Fig. 2. Partial pressures of a-b oxygen $\left(\mathrm{PO}_{2}\right)$ and $\mathbf{c}-\mathbf{d}$ carbon dioxide $\left(\mathrm{PCO}_{2}\right)$ in silver catfish $(\mathrm{n}=6)$ (Rhamdia quelen) submitted to different concentrations of essential oils from the linalool (EO-L) and citral (EO-C) chemotypes of Lippia alba. Values are mean \pm SEM. Different letters indicate significant difference between times within the same EO concentration. * indicate significant difference from control, \# indicate significant difference from ethanol. Two-way ANOVA and Tukey's test or Scheirer-Ray-Hare extension of the Kruskal-Wallis test and Nemenyi test.
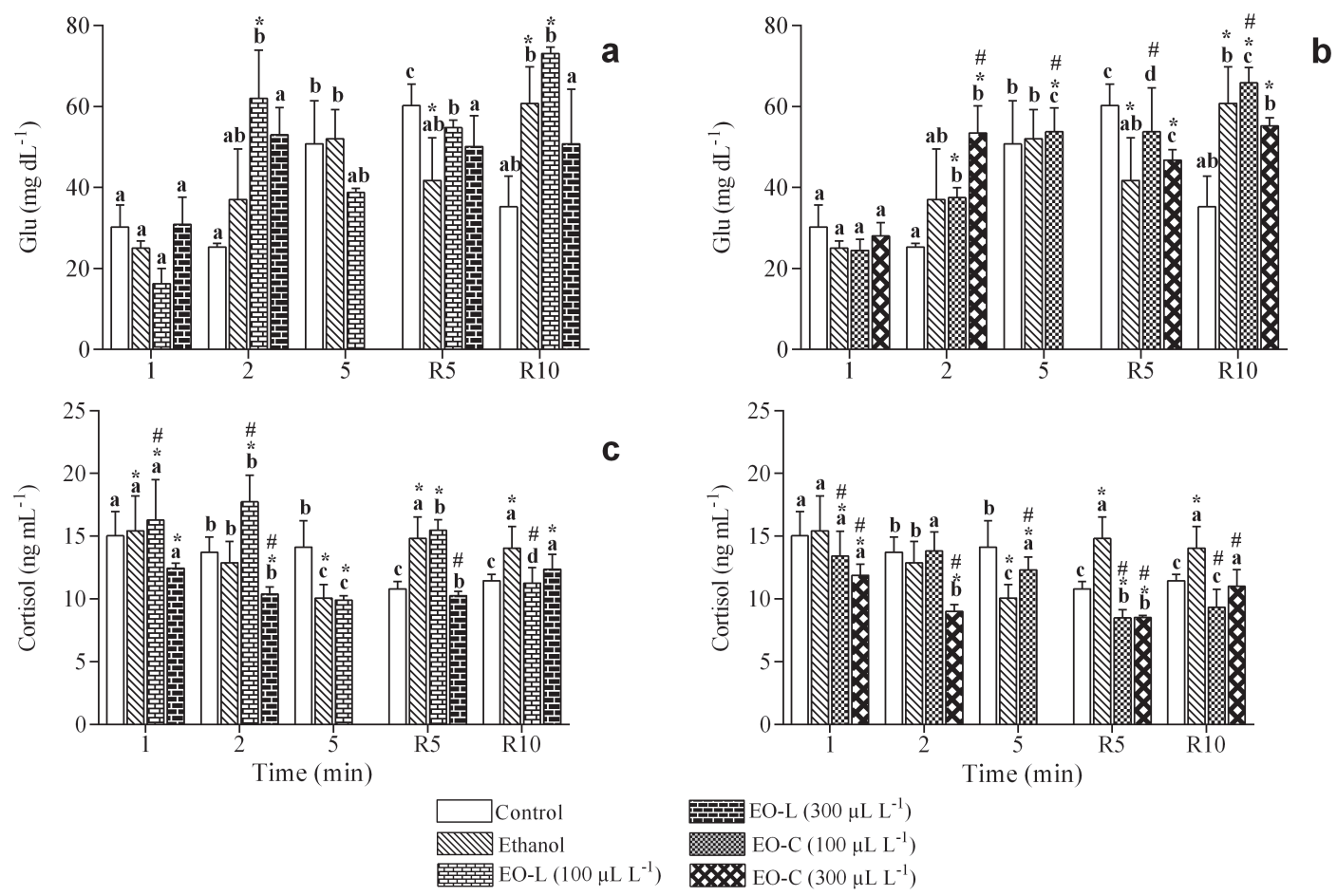

Fig. 3. a-b. Blood glucose (Glu) and c-d. plasma cortisol in silver catfish (Rhamdia quelen) $(\mathrm{n}=6)$ subjected to different concentrations of essential oils from the linalool (EO-L) and citral (EO-C) chemotypes of Lippia alba. Values are mean \pm SEM. Different letters indicate significant differences between times within the same treatment. * indicates significant difference from control, \# indicates significant difference from ethanol. Two-way ANOVA and Tukey's test or Scheirer-RayHare extension of the Kruskal-Wallis test and Nemenyi test were used to determine statistical significance. 


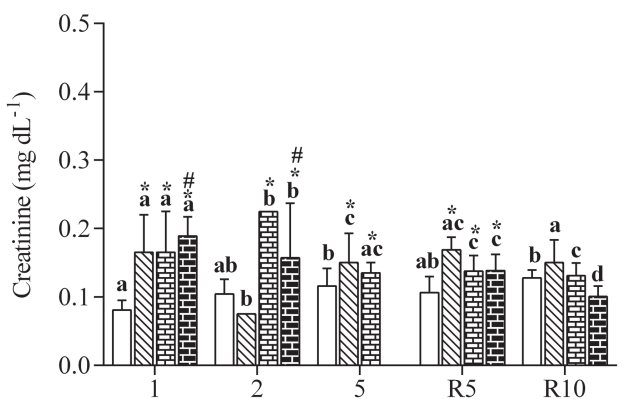

a
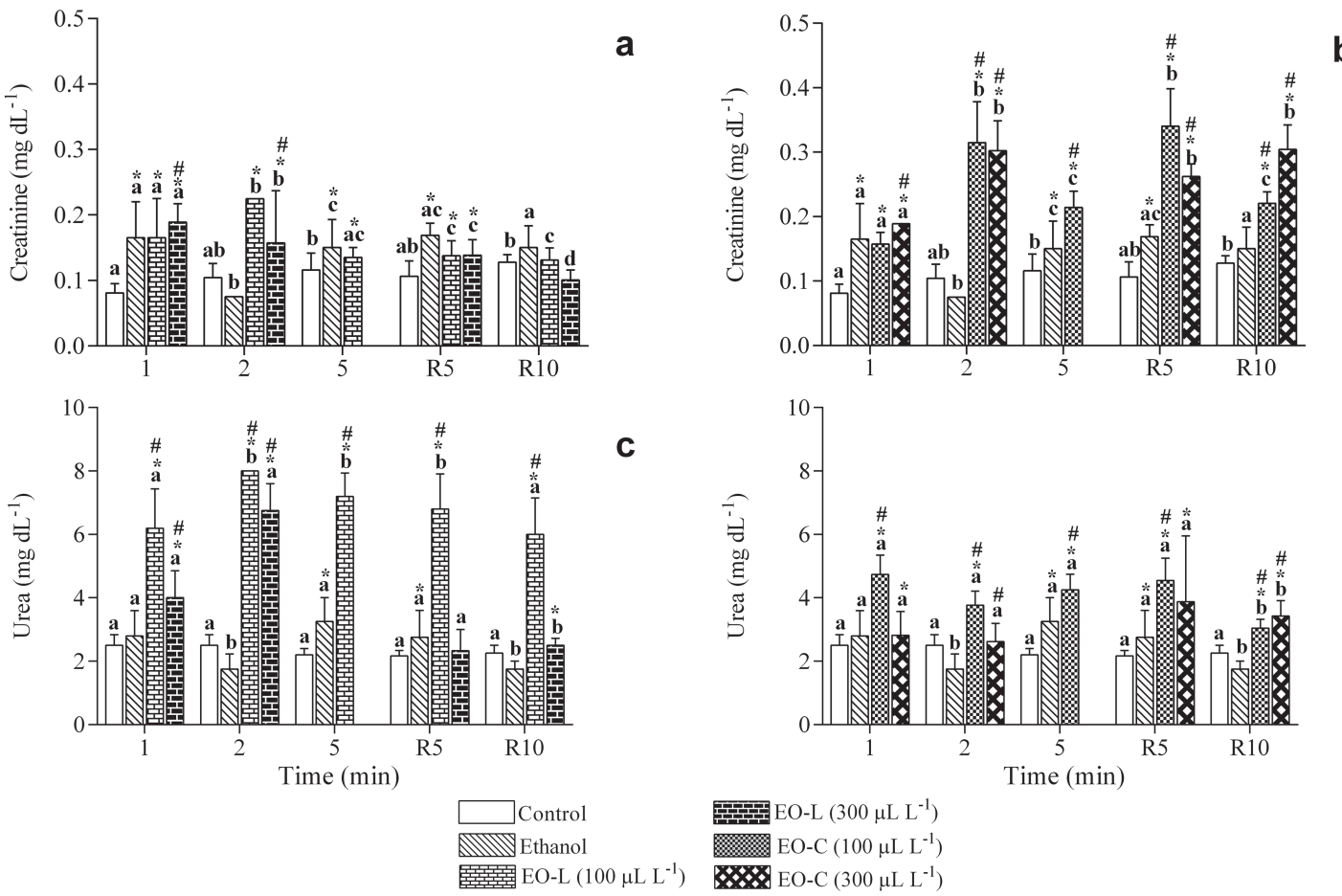

Fig. 4. a-b. Plasma urea and $\mathbf{c - d}$ creatinine in silver catfish (Rhamdia quelen) $(\mathrm{n}=6)$ subjected to different concentrations of essential oils from the linalool (EO-L) and citral (EO-C) chemotypes of Lippia alba. Values are mean \pm SEM. Different letters indicate significant differences between times within the same treatment. * indicates significant difference from control, \# indicates significant difference from ethanol. Two-way ANOVA and Tukey's test or Scheirer-Ray-Hare extension of the Kruskal-Wallis test and Nemenyi test were used to determine statistical significance.

\section{Discussion}

Since EOs represent a chemical interface between plant and the surrounding environment, their syntheses are often affected by environmental conditions, thus expressing the occurrence of chemotypes or chemical races in the producing plant species (Gobbo-Neto, Lopes, 2007). Although there are many examples of the occurrence of geographic variations of EOs chemical composition in several plants (Figueiredo et al., 2008), the distribution of chemotypes is often not locally limited. In some species, different chemotypes can grow side by side (Schmidt et al., 2004).

The present study demonstrates that the EO from $L$. alba cultivated by our group in southern Brazil has linalool as its main compound (50.56\%), and so it belongs to chemotype linalool. On the other hand, L. alba collected in northern Brazil can be classified in the chemotype citral, once this is the major compound of its EO (54.26\%). Some authors indicated that geographical distribution and exposure to different soil and weather conditions, season of collection can affect the chemical composition of $L$. alba EO (Pascual et al., 2001; Hennebelle et al., 2008; Maffei et al., 2011; Teles et al., 2012). However, specimens from the chemotypes citral, linalool and carvone, collected in different regions of Brazil, cultivated in similar conditions, maintained the same chemical composition, indicating that differences are due to genotypic variations (Tavares et al., 2005).
The EO-C anesthetized silver catfish within approximately $2 \mathrm{~min}$ at $300 \mu \mathrm{L} \mathrm{L}^{-1}$, inducing anesthesia faster than EO-L. Anesthesia recovery was slower with EO$\mathrm{C}$, but it can be considered and adequate anesthetic for silver catfish, because an ideal anesthetic must induce anesthesia up to $3 \mathrm{~min}$ and enable the recovery in about $10 \mathrm{~min}$ (Park et al., 2008). The anesthetic effect of EO-L in silver catfish involves the modulation of the benzodiazepine (BDZ) site of the GABAergic system (Heldwein et al., 2012). The EO-C blocks the excitability of rat sciatic nerves (Sousa et al., 2015), but the anesthetic effect of the EO from Aloysia triphylla (which has citral as its major compound) in silver catfish is not related to a modulation of the BDZ site of the GABAA receptor (Santos et al., in press).

All parameters examined in this study are within the range previously observed for silver catfish (Barcellos et al., 2001 ; 2004). Blood $\mathrm{Na}^{+}, \mathrm{K}^{+}$and $\mathrm{Ca}^{2+}$ of silver catfish were not affected by anesthesia with either EO tested. Similar results were found in the blood of Amazon catfish (Leiarius marmoratus) anesthetized with $10-200 \mu \mathrm{L} \mathrm{L}^{-1}$ eugenol (Honorato et al., 2014) and in the plasma of silver catfish anesthetized with 150 and $300 \mathrm{mg} \mathrm{L}^{-1} \mathrm{MS}-222$ (Gressler et al., 2014). However, silver catfish anesthetized with 150$450 \mu \mathrm{L} \mathrm{L}^{-1}$ of Hesperozygis ringens and Lippia alba (EOL) showed altered plasma $\mathrm{Na}^{+}$and $\mathrm{K}^{+}$between 30-240 min of recovery (Toni et al., 2014) and anesthesia of tambaqui with $20 \mathrm{mg} \mathrm{L}^{-1}$ jambu extract induced blood ionoregulatory 
changes $2 \mathrm{~h}$ after recovery from anesthesia and $\mathrm{Na}^{+}$levels did not return to control values, even after $72 \mathrm{~h}$ (Barbas et al., 2016). Apparently ionoregulatory effects of anesthesia in blood or plasma are significant only after a few hours of recovery, when they can be detected.

During fish anesthesia, opercular movement (respiration) generally decreases compared to conscious fish, explaining the lower blood $p \mathrm{O}_{2}$ in silver catfish anesthetized with both EOs and the higher $p \mathrm{CO}_{2}$ in those anesthetized with EO-C. Through anesthetic recovery from both EOs there was an increase in blood $p \mathrm{O}_{2}$ levels and a reduction in $p \mathrm{CO}_{2}$ levels in those exposed to EO-C, which is expected for the recovery period with normal return of opercular movements. These same oscillation patters in $p \mathrm{O}_{2}$ and $p \mathrm{CO}_{2}$ from fish anesthesia, were found for red "pacu" (Piaractus brachypomus) anesthetized with MS-222 (150 $\left.\mathrm{mg} \mathrm{L}^{-1}\right)$ (Hanley et al., 2010) and "tambaqui" (Colossoma macropomum) anesthetized with waxy extract of "jambu" flowers (Spilanthes acmella) at $20 \mathrm{mg} \mathrm{L}^{-1}$ (Barbas et al., 2016).

An increase in plasma levels of glucocorticoids such as cortisol is one of the main responses to stress (Barton, 2002). Plasma cortisol increases significantly in juvenile $R$. quelen 5 - 30 min after handling (Koakoski et al., 2012), but surprisingly, handling was not sufficient to raise the plasma cortisol in the control group of silver catfish in our study. Toni et al. (2015) observed no increase in plasma cortisol levels of silver catfish exposed for $6 \mathrm{~h}$ to 30 and $50 \mu \mathrm{L} \mathrm{L}^{-1}$ EO from Hesperozygis ringens and they proposed that the primary stress reaction only took place in the first minutes after contact with the EO, as observed in fish exposed to EO-L in the present study.

A study by Gesto et al. (2014) using stressed rainbow trout (Oncorhynchus mykiss) showed that when catecholamines were released in the blood no changes in cortisol levels were observed as glucose levels increased. As plasma cortisol levels did not increase significantly, we suppose that the increase of blood glucose in silver catfish observed in the present study might be due to catecholamine release. According to Morgan, Iwama (1997), an increase in blood glucose occurs in response to a stressor, in order to provide most of the energy demand to cope with this stress. Our results corroborate those obtained by Inoue et al. (2011) and Honorato et al. (2014), who observed that anesthesia with eugenol increased plasma glucose compared to the sham control in "tambaqui" (20 and $\left.60 \mathrm{mg} \mathrm{L}^{-1}\right)$ and Amazon catfish (10-200 $\left.\mu \mathrm{L} \mathrm{L}^{-1}\right)$. Anesthesia with $20 \mathrm{mg} \mathrm{L}^{-1}$ "jambu" extract also increased blood glucose levels in "tambaqui" (Barbas et al., 2016). Several studies testing a variety of anesthetics on multiple fish species also demonstrated increased glycemia after anesthesia induction (Ortuno et al., 2002; Deriggi et al., 2006; Barbosa et al., 2007; Park et al., 2008).

An increase in plasma urea levels in silver catfish during anesthesia and recovery was observed for both EOs when compared to the control group. The same result was obtained for plasma creatinine levels, but these levels were much higher in silver catfish anesthetized with EO-C than in control fish, and these levels returned to control values after $10 \mathrm{~min}$ recovery in those exposed to EO-L. Anesthesia of goldfish (Carassius auratus) with $50 \mu \mathrm{L}$ $\mathrm{L}^{-1}$ nanoencapsulated clove oil also increased serum urea levels (Gholipourkanani et al., 2015). Increases in urea and creatinine levels together are probably due to lesions caused in the kidney of fish (Das, Mukherjee, 2003). Studies conducted by Borges et al. (2007) showed an increase in urea and creatinine levels in the serum of silver catfish exposed to cypermethrin, suggesting that these analyses can be useful for early detection of intoxication in fish. However, as nitrogen compounds are excreted as ammonia mainly through the gills (Nawata et al., 2007), and time of exposure to the EOs was brief, the elevation of urea levels observed in both EO groups in our study may be due to changes in ammonia and creatinine gill excretion and not to renal lesions.

In summary, different chemotypes of $L$. alba were detected according to their place of cultivation. We suggest that the EO-L and EO-C can be safely used as anesthetics in silver catfish, because the alterations in most parameters returned to control values within $10 \mathrm{~min}$. However, the EO obtained from different chemotypes of the L. alba presented different physiological responses in plasma creatinine and the use of EO-L is preferable because the high creatinine levels provoked by EO-C exposure. Additional studies with longer exposure and/or recovery times are necessary to improve our understanding of the effects of the EO of this chemotype on renal function.

\section{Acknowledgments}

The authors are grateful to the Conselho Nacional de Desenvolvimento Científico e Tecnológico (CNPq), Comissão de Aperfeiçoamento de Pessoal de Nível Superior (CAPES), Fundação de Amparo à Pesquisa do Estado do Rio Grande do Sul (FAPERGS-PRONEX), Ministério da Pesca e Aquicultura/Ministério da Ciência e Tecnologia/ FINEP and INCT-ADAPTA (CNPq - FAPEAM).

\section{References}

Adams RP. Identification of essential oil components by gas chromatography/quadrupole mass spectroscopy. 3rd ed. Illinois: Allured Publishing Corporation; 2001.

Aldrin JF, Messager L, Laurencin FB. La biochimie clinique en aquaculture. Actes Colloq. 1982: 14, 219-326.

Araújo CSO, Tavares-Dias M, Gomes ALS, Andrade SMS, Lemos JRG, Oliveira AT et al. Infecções parasitárias e parâmetros sanguíneos em Arapaima gigas Schinz, 1822 (Arapaimidae) cultivados no estado do Amazonas, Brasil. In: Tavares-Dias, M, organizer. Manejo e sanidade de peixes em cultivo. Macapá: Embrapa Amapá; 2009. p.389-424.

Barbosa LG, Moraes G, Inoue LAKA. Respostas metabólicas do matrinxã submetido a banhos anestésicos de eugenol. Acta Sci Biol Sci. 2007; 29(3):255-60. 
Barbas LAL, Stringhetta GR, Garcia LO, Figueiredo MRC, Sampaio LA. Jambu, Spilanthes acmella as a novel anaesthetic for juvenile tambaqui, Colossoma macropomum: secondary stress responses during recovery. Aquaculture. 2016; 456:70-75.

Barcellos LJG, Woehl VM, Wassermann GF, Quevedo RM, Ittzés I, Krieger MH. Plasma levels of cortisol and glucose in response to capture and tank transference in Rhamdia quelen (Quoy \& Gaimard), a South American catfish. Aquacult Res. 2001; 32(2):121-23.

Barcellos LJG, Conrad J, Kreutz LC, Souza C de, Rodrigues LB, Fioreze I, et al. Hematological changes in jundiá (Rhamdia quelen Quoy and Gaimard Pimelodidae) after acute and chronic stress caused by usual aquacultural management, with emphasis on immunosuppressive effects. Aquaculture. 2004; 237(1-4):229-36.

Barton BA, Iwama GK. Physiological changes in fish from stress in aquaculture with emphasis on the responses and effects of corticosteroids. Annu Rev Fish Dis. 1991; 1:3-26.

Barton BA. Stress in fishes: a diversity of responses with particular reference to changes in circulating corticosteroids. Integr Comp Biol. 2002; 42(3):517-25.

Becker AG, Parodi TV, Heldwein CG, Zeppenfeld CC, Heinzmann BM, Baldisserotto B.. Transportation of silver catfish, Rhamdia quelen, in water with eugenol and the essential oil of Lippia alba. Fish Physiol Biochem. 2012; 38(3):789-96.

Borges A, Scotti LV, Siqueira DR, Zanini R, Amaral FD, Jurinitz DF et al. Changes in hematological and serum biochemical values in Jundiá Rhamdia quelen due to sub-lethal toxicity of cypermethrin. Chemosphere. 2007; 69(6):920-26.

Cnaani A, Tinman S, Avidar Y, Ron M, Hulata G. Comparative study of biochemical parameters in response to stress in Oreochromis aureus, O. mossambicus and two strains of $O$. niloticus. Aquacult Res. 2004; 35(15):1434-40.

Cunha MA, Barros FMC, Garcia LO, Veeck APL, Heinzmann BM, Loro VL et al. Essential oil of Lippia alba: A new anesthetic for silver catfish, Rhamdia quelen. Aquaculture. 2010; 306(14):403-06.

Das BK, Mukherjee SC. Toxicity of cypermethrin in Labeo rohita fingerlings: biochemical, enzymatic and haematological consequences. Comp Biochem Physiol C Toxicol Pharmacol. 2003; 134(1):109-21.

Deriggi FG, Inoue LAKA, Moraes G. Stress responses to handling in Nile tilapia (Oreochromis niloticus Linnaeus): assessment of eugenol as an alternative anesthetic. Acta Sci Anim Sci. 2006; 28(3):269-74

Figueiredo AC, Barroso JG, Pedro LG, Scheffer JJC. Factors affecting secondary metabolite production in plants: volatile components and essential oils. Flavour Frag J. 2008; 23(4):213-26.

Gesto M, Otero-Rodiño C, López-Patiño MA, Míguez JM, Soengas JL, Conde-Sieira M. Is plasma cortisol response to stress in rainbow trout regulated by catecholamine-induced hyperglycemia? Gen Comp Endocrinol. 2014; 205:207-17.

Gholipourkanani H, Gholinasab-Omran I, Ebrahimi P, Jafaryan H. Anesthetic effect of clove oil loaded on lecithin based nano emulsions in gold fish, Carassius auratus. J Fish Aquat Sci. 2015; 10(6):553-61.
Gobbo-Neto L, Lopes NP. Plantas medicinais: fatores de influência no conteúdo de metabólitos secundários. Quím Nova. 2007; 30(2):374-81.

Gressler LT, Riffel APK, Parodi TV, Saccol EMH, Koakoski G, Costa ST et al. Silver catfish Rhamdia quelen immersion anaesthesia with essential oil of Aloysia triphylla (L'Hérit) Britton or tricaine methanesulfonate: effect on stress response and antioxidant status. Aquacult Res. 2014; 45(6):1061-72.

Hanley CS, Clyde VL, Wallace RS, Paul-Murphy J, Patterson TA, Keuler NS et al. Effects of anesthesia and surgery on serial blood gas values and lactate concentrations in yellow perch (Perca flavescens), walleye pike (Sander vitreus), and koi (Cyprinus carpio). J Am Vet Med Assoc. 2010; 236(10):1104-08.

Harrenstien LA, Tornquist SJ, Miller-Morgan TJ, Fodness BG, Clifford KE. Evaluation of a point-of-care blood analyzer and determination of reference ranges for blood parameters in rockfish. J Am Vet Med Assoc. 2005; 226(2):255-65.

Heldwein CG, Silva LL, Reckziegel P, Barros FMC, Bürger ME, Baldisserotto B et al. Participation of the GABAergic system in the anesthetic effect of Lippia alba (Mill.) N. E. Brown essential oil. Braz J Med Biol Res. 2012; 45(5):436-43.

Heldwein CG, Silva LL, Gai EZ, Roman C, Parodi TV, Bürger ME et al. S-(+)-Linalool from Lippia alba: Sedative and anesthetic for silver catfish (Rhamdia quelen). Vet Anaesth Analg. 2014; 41(6):621-29.

Hennebelle T, Sahpaz S, Joseph H, Bailleul F. Ethnopharmacology of Lippia alba. J Ethnopharmacol. 2008; 116(2):211-22.

Hohlenwerger JC, Copatti CE, Sena AC, Couto RD, Baldisserotto B, Heinzmann BM et al. Could the essential oil of Lippia alba provide a readily available and cost-effective anaesthetic for Nile tilapia (Oreochromis niloticus)? Mar Freshw Behav Physiol. 2016; 49(2):119-26.

Honorato CA, Dambros A, Marcondes VM, Nascimento CA. Utilização do eugenol em jundiá da Amazônia (Leiarius marmoratus): implicações na sedação e avaliação hemogasométrica. Semin-Ciênc Agrár. 2014; 35(5):2759-68.

Inoue LAKA, Boijink CL, Ribeiro PT, Silva AMD, Affonso EG. Avaliação de respostas metabólicas do tambaqui exposto ao eugenol em banhos anestésicos. Acta Amaz. 2011; 41(2):327-32.

Jacobs E, Vadasdi E, Sarkozi L, Coman N. Analytical evaluation of i-STAT ${ }^{\circledR}$ portable clinical analyzer and use by non-laboratory health-care professionals. Clin Chem. 1993; 39(6):1069-74.

Kiessling A, Johansson D, Zahl IH, Samuelsen OB. Pharmacokinetics, plasma cortisol and effectiveness of benzocaine, MS-222 and isoeugenol measured in individual dorsal aorta-cannulated Atlantic salmon (Salmo salar) following bath administration. Aquaculture. 2009; 286(34):301-08.

Koakoski G, Oliveira TA, Rosa JGS, Fagundes M, Kreutz LC, Barcellos LJG. Divergent time course of cortisol response to stress in fish of different ages. Physiol Behav. 2012; 106(2):129-32.

Kristensen T, Rosseland BO, Kiessling A, Djordevic B, Massabau JC. Lack of arterial $\mathrm{pO}_{2}$ down regulation in Atlantic salmon (Salmo salar L.) during long-term normoxia and hyperoxia. Fish Physiol Biochem. 2010; 36(4):1087-95. 
Liew HJ, Fazio A, Faggio C, Blust R, De Boeck G. Cortisol affects metabolic and ionoregulatory responses to a different extent depending on feeding ration in common carp, Cyprinus carpio. Comp Biochem Physiol A Mol Integr Physiol. 2015; 189:45-57.

Maffei ME, Gertsch J, Appendino G. Plant volatiles: production, function and pharmacology. Nat Prod Rep. 2011; 28(8):1359-80.

McDonald G, Milligan L. Ionic, osmotic and acid base regulation in stress. In: Iwama, GK, Pickering AD, Sumpter JP, Schreck $\mathrm{CB}$, editors. Fish stress and health in aquaculture. Cambridge: Cambridge University Press; 1997. p.119-144.

Morgan JD, Iwama GK. Measurements of stressed states in the field. In: Iwama, GK, Pickering AD, Sumpter JP, Schreck $\mathrm{CB}$, editors. Fish stress and health in aquaculture. Cambridge: Cambridge University Press; 1997. p.247-270.

Nawata CM, Hung CCY, Tsui TKN, Wilson JM, Wright PA, Wood CM. Ammonia excretion in rainbow trout (Oncorhynchus mykiss): evidence for $\mathrm{Rh}$ glycoprotein and $\mathrm{H}^{+}$-ATPase involvement. Physiol Genomics. 2007; 31(3):463-74.

Neiffer DL, Stamper MA. Fish sedation, anesthesia, analgesia and euthanasia: consideration, methods and types of drugs. ILAR J. 2009; 50(4):343-60.

Neto AC, Netto JC, Pereira PS, Pereira AMS, Taleb-Contini $\mathrm{SH}$, França SC et al. The role of polar phytocomplexes on anticonvulsant effects of leaf extracts of Lippia alba (Mill.) N.E. Brown chemotypes. J Pharm Pharmacol. 2009: 61(7):933-39.

NIST/EPA/NIH. Mass spectral library and search/analysis programs. John Wiley and Sons, Hoboken; 2002.

Oliveira DR, Leitão GG, Santos SS, Bizzo HR, Lopes D, Alviano CS et al. Ethnopharmacological study of two Lippia species from Oriximiná, Brazil. J Ethnopharmacol. 2006; 108:103-08.

Ortunõ J, Esteban MA, Meseguer J. Effects of four anaesthetics on the innate immune response of gilthead seabream (Sparus aurata L.). Fish Shellfish Immunol. 2002; 12(1):49-59.

Park MO, Hur WJ, Im SY, Seol DW, Lee J, Park IS. Anaesthetic efficacy and physiological responses to clove oil anaesthetized kelp grouper Epinephelus bruneus. Aquacult Res. 2008; 39(8):877-84.

Parodi TV, Cunha MA, Becker AG, Zeppenfeld CC, Martins DI, Koakoski G et al. Anesthetic activity of Aloysia triphylla and effectiveness in reducing stress during transport of albine and grey strains of silver catfish, Rhamdia quelen. Fish Physiol Biochem. 2014; 40(2):323-34.

Pascual ME, Slowing K, Carretero E, Sánchez Mata D, Villar A. Lippia: traditional uses, chemistry and pharmacology: a review. J Ethnopharmacol. 2001; 76(3):201-14.

Pidetcha P, Ornvichian S, Chalachiva S. Accuracy and precision of the i-STAT ${ }^{\circledR}$ portable clinical analyzer: an analytical point of view. J Med Assoc Thai. 2000; 83(4):445-50.

Roohi Z, Imanpoor MR. The efficacy of the oils of spearmint and methyl salicylate as new anesthetics and their effect on glucose levels in common carp (Cyprinus carpio L., 1758) juveniles. Aquaculture. 2015; 43:327-32.

Ross LG, Ross B. Anaesthetic and sedative techniques for aquatic animals. 3rd ed. Oxford: Blackwell Publishing; 2008.
Roth B, Rotabakk BT. Stress associated with commercial longlining and recreational fishing of saithe (Pollachius virens) and the subsequent effect on blood gases and chemistry. Fish Res. 2012;115-116:110-14.

Roubach R, Gomes LC, Fonseca FAL, Val AL. Eugenol as an efficacious anaesthetic for tambaqui, Colossoma macropormum(Cuvier). Aquacult Res. 2005; 36(11):105661.

Salbego J, Becker AG, Gonçalves JF, Menezes CC, Heldwein CG, Spanevello RM et al. The essential oil from Lippia alba induces biochemical stress in the silver catfish (Rhamdia quelen) after transportation. Neotrop Ichthyol. 2014; 12(4):811-18.

Santos AC, Junior GB, Zago DC, Zeppenfeld CC, Silva DT, Heinzmann BM et al. Anesthesia and anesthetic action mechanism of essential oils of Aloysia triphylla and Cymbopogon flexuosus in silver catfish (Rhamdia quelen). Vet Anaesth Analg. Forthcoming 2017.

Schmidt A, Bischof-Deichnik C, Stahl-Biskup E. Essential oil polymorphism of Thymus praecox subsp. arcticus on the British Isles. Biochem Syst Ecol. 2004; 32(4):409-21.

Silva LL, Parodi TV, Rekcziegel P, Garcia VO, Bürger ME, Baldisserotto B et al. Essential oil of Ocimum gratissimum L.: anesthetic effects, mechanism of action and tolerance in silver catfish, Rhamdia quelen. Aquaculture. 2012; 350-353:91-97.

Silva LL, Garlet QI, Benovit SC, Dolci G, Mallmann CA, Bürger ME et al. Sedative and anesthetic activities of the essential oils of Hyptis mutabilis (Rich) Briq. and their isolated components in silver catfish (Rhamdia quelen). Braz J Med Biol Res. 2013a; 46(4):771-79.

Silva LL, Silva DT, Garlet QI, Cunha MA, Mallmann CA, Baldisserotto $\mathrm{B}$ et al. Anesthetic activity of Brazilian native plants in silver catfish (Rhamdia quelen). Neotrop Ichthyol. 2013b; 11(2):443-51.

Silva LL, Garlet QI, Koakoski G, Oliveira TA, Barcellos LJG, Baldisserotto B et al. Effects of anesthesia with the essential oil of Ocimum gratissimum L. in parameters of fish stress. Rev Bras Plant Med. 2015; 17(2):215-23.

Small BC. Anesthetic efficacy of metomidate and comparison of plasma cortisol responses to tricaine methanesulfonate, quinaldine and clove oil anesthetized channel catfish Ictalurus punctatus. Aquaculture. 2003; 218(1-4):177-85.

Soares BV, Neves LR, Oliveira MSB, Chaves FCM, Dias MKR, Chagas EC et al. Antiparasitic activity of the essential oil of Lippia alba on ectoparasites of Colossoma macropomum (tambaqui) and its physiological and histopathological effects. Aquaculture. 2016; 452:107-14.

Sousa DG, Sousa SDG, Silva RER, Silva-Alves KS, Ferreira-daSilva FW, Kerntopf MR et al. Essential oil of Lippia alba and its main constituent citral block the excitability of rat sciatic nerves. Braz J Med Biol Res. 2015; 48(8):697-702.

Souza CF, Salbego J, Gressler LT, Golombieski JI, Ferst JG, Cunha MA et al. Rhamdia quelen (Quoy \& Gaimard, 1824), submitted to a stressful condition: effect of dietary addition of the essential oil of Lippia alba on metabolism, osmoregulation and endocrinology. Neotrop Ichthyol. 2015; 13(4):707-14. 
Takahashi LS, Abreu JS, Biller JD, Urbinati EC. Efeito do ambiente pós-transporte na recuperação dos indicadores de estresse de pacus juvenis, Piaractus mesopotamicus. Acta Sci Anim Sci. 2006; 28(4):469-75.

Tavares ES, Julião LS, Lopes D, Bizzo HR, Lage CLS, Leitão SG. Análise do óleo essencial de folhas de três quimiotipos de Lippia alba (Mill.) N. E. Br. (Verbenaceae) cultivados em condições semelhantes. Rev Bras Farmacogn. 2005; 15(1):1-5.

Tavares-Dias M, Moraes FR, Imoto ME. Hematological parameters in two neotropical freshwater teleost, Leporinus macrocephalus (Anostomidae) and Prochilodus lineatus (Prochilodontidae). Biosci J. 2008; 24(3):96-101.

Teles S, Pereira JA, Santos CHB, Menezes RV, Malheiro $\mathrm{R}$, Lucchese AM et al. Geographical origin and drying methodology may affect the essential oil of Lippia alba (Mill) N.E. Brown. Ind Crops Prod. 2012; 37(1):247-52.

Toni C, Becker AG, Simões LN, Pinheiro CG, Silva LL, Heinzmann BM et al. Fish anesthesia: Effects of the essential oils of Hesperozygis ringens and Lippia alba on the biochemistry and physiology of silver catfish (Rhamdia quelen). Fish Physiol Biochem. 2014; 40(3):701-14.

Toni C, Martos-Sitcha JA, Ruiz-Jarabo I, Mancera JM, MartínezRodríguez G, Pinheiro CG et al. Stress response in silver catfish (Rhamdia quelen) exposed to the essential oil of Hesperozygis ringens. Fish Physiol Biochem. 2015; 41(1):129-38.
Vale TG, Furtado EC, Santos Júnior JG, Viana GSB. Central effects of citral, myrcene and limonene, constituents of essential oil chemotypes from Lippia alba (Mill.) N.E. Brown. Phytomedicine. 2012; 9(8):709-14.

Viccini LF, Silveira RS, Vale AA, Campos JMS, Reis AC, Santos MO et al. Citral and linalool content has been correlated to DNA content in Lippia alba (Mill.) N.E. Brown (Verbenaceae). Ind Crops Prod. 2014; 59:14-19.

Wendelaar Bonga SE. The stress response in fish. Physiol Rev. 1997; 77(3):591-625.

Zétola M, Lima TC, Sonaglio D, Gonzalez-Ortega G, Limberger RP, Petrovick PR et al. CNS activities of liquid and spraydried extracts from Lippia alba-Verbenaceae (Brazilian false melissa). J Ethnopharmacol. 2002; 82(2-3):207-15.

Submitted June 9, 2016

Accepted December 23, 2016 by Juan Miguel Mancera 